\title{
The development of forced degradation studies for the determination of daptomycin in urine at various conditions by using RP-LC method
}

\author{
Bediha AKMEŞE 1 (D), Nurgül K. BAKIRHAN 1 * (D) , Tuğçe GÖVER ${ }^{2}$ (D) , Sibel A. ÖZKAN ${ }^{3}$ (D) \\ 1 Department of Chemistry, Faculty of Art and Science, Hitit University, Çorum, Turkey. \\ 2 Department of Analytical Chemistry, Faculty of Pharmacy, Selçuk University, Konya, Turkey. \\ 3 Department of Analytical Chemistry, Faculty of Pharmacy, Ankara University, Ankara, Turkey. \\ * Corresponding Author. E-mail: nurgulk44@gmail.com (N.K.B.); Tel. +90-364-227 7001.
}

Received: 25 September 2018 / Revised: 23 October 2018 / Accepted: 31 October 2018

\begin{abstract}
Daptomycin is known as the first lipopeptide antibiotic shows activity against gram-positive bacteria. A fast, simple and repeatabile RP-LC method has been developed for the determination of daptomycin in mobile phase solution and human urine. This drug was exposed to various stress conditions such as hydrolytic, oxidative, thermal and photolytic and the stressed samples were detected by the proposed method. Daptomycin was well separated on a X-Terra RP-18 column using the mobile phase consisting of a mixture of acetonitrile:water (45:55 v/v) at a flow rate of $1 \mathrm{~mL} \mathrm{~min}-1$. The system operates at $222 \mathrm{~nm}$ for daptomycin and $319 \mathrm{~nm}$ and tinidazole was used as internal standard under these conditions. The linearity of daptomycin was obtained between 0.50 and $12 \mu \mathrm{g} \mathrm{mL}^{-1}$ concentration range. Limits of detection was determined as 0.1176 and $0.1412 \mu \mathrm{g} \mathrm{mL}-1$ and the limits of quantification was obtained as 0.3563 and $0.4277 \mu \mathrm{g} \mathrm{mL}^{-1}$ in the mobile phase and urine, respectively. Hydrochloric acid, sodium hydroxide, hydrogen peroxide affected response of daptomycin under stress degradation conditions.
\end{abstract}

KEYWORDS: Drug; daptomycin; degradation conditions; high performance liquid chromatography.

\section{INTRODUCTION}

Antibiotics are used to treat infections caused by bacteria in medical science. Some bacteria may become resistant to frequently used antibiotics. When these antibiotics fail, other antibiotics are used as defenses against infections. One of these antibiotics mentioned as a last resort is daptomycin (DPT) (Figure 1). DPT has the cytoplasmic membrane and it is known to be limited to gram positive bacteria and to be calcium-dependent [1]. Gram-positive organisms have both susceptible and methicillin resistant strains of Staphylococcus aureus (MRSA) and DPT is a powerful antibiotic used in the treatment of complicated skin and soft tissue infections caused by these organisms [2]. In some studies it has been reported that the use of high doses of DPT increases the rate and speed of bactericidal activity and it has been successfully used in the treatment of some bacterial infectious patients who are difficult to treat [3-5].

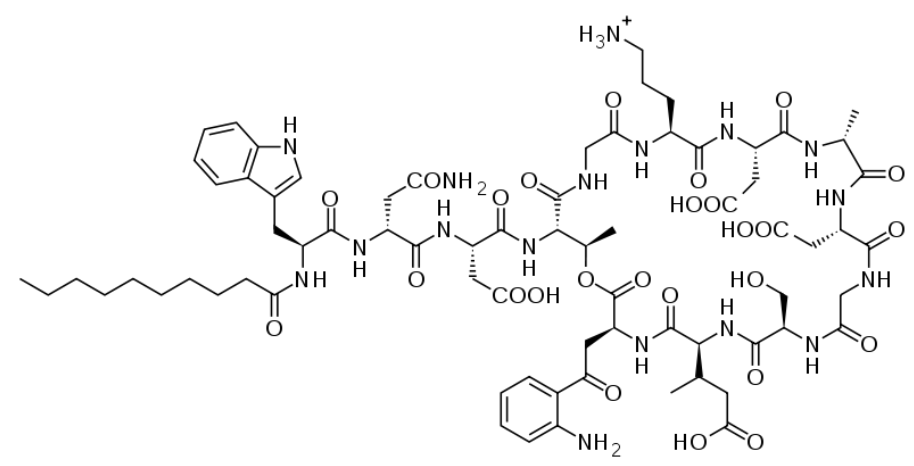

Figure 1. Structure of daptomycin.

How to cite this article: Akmeşe B, Bakırhan NK, Göver T, Özkan SA. The development of forced degradation studies for the determination of daptomycin in urine at various conditions by using RP-LC method. J Res Pharm. 2019; 23 (2): 170-176. 
Some LC methods have been reported for the determination of DPT in biological fluids like serum, plasma and blood [6-8] and pharmaceutical dosage forms [9, 10].

Purpose of degradation studies is to create degradation ways of drug samples and to determine degradation products. These studies present the mechanism of degradation of the drug substance and their products and to clarify the intrinsic stability of the formulation, to solve the problems related to stability and to be able to explain the chemical properties of drug molecules [11, 14].

The aim of this study was to develop and validate HPLC method to determine the amount of DPT in degraded samples and also, the results will be compared with similar studies in the literature. The results showed that the proposed method is suitable for monitoring DPT in biological fluid such as human urine.

\section{RESULTS}

The effect of colomn, mobile phase, $\mathrm{pH}$ on the mobile phase, flow rate and column temperature were investigated to find the optimum chromatographic conditions for RP-LC analysis of DPT. Several column types were tried (Gemini RP-18 (250 mm x $4.6 \mathrm{~mm}$ ID $\times 5 \mu \mathrm{m})$, Termo Hypersil Gold RP-18 $(175 \mathrm{~mm} \times 5 \mathrm{~mm}$ ID $\times 2.5 \mu \mathrm{m})$ and X-Terra RP-18 (250 mm x $4.60 \mathrm{~mm}$ ID $\times 5 \mu \mathrm{m})$ and X-Terra RP-18 selected as optimum column with best peak asymmetry. Acetonitrile-water mixture was used at different ratios as the mobile phase and $45: 50 \%$ (v/v) ACN-water mixture was selected. Mobile phase was examined at several $\mathrm{pH}$ such as 3.0, 3.5, $4.0,4.5,5.0$ and $\mathrm{pH} 3.0$ was observed as optimum $\mathrm{pH}$ value with best peak asymmetry and retention values. Orthophosphoric acid $(20 \mathrm{mM})$ was used for adjusting $\mathrm{pH}$ of mobile phase solution. Different flow rates were tried such as $0.8,0.9,1,1.1$ and $1.2 \mathrm{~mL}$ min- 1 and flow rate was determined as $1 \mathrm{~mL}$ min-1. The temperature effect of column on the setting of response was investigated between 25 and $30^{\circ} \mathrm{C}$. According to the results of temperature study, $25^{\circ} \mathrm{C}$ was observed as best temperature for fast response, good peak shape and repeatability properties of DPT. Finally, ACN:water 45:50 (v/v) mixture adjusted with $20 \mathrm{mM} \mathrm{H}_{3} \mathrm{PO}_{4}(\mathrm{at} \mathrm{pH}=3)$ at a flow rate of $1 \mathrm{~mL}$ min-1 as mobile phase was chosen as the most suitable carrier for RP-LC analysis. After determining the optimum conditions, a satisfactory resolution was obtained in a short analysis time as less than 6 min (Fig.2). Symmetrical, sharp and well-resolved peaks were obtained for DPT and IS using $222 \mathrm{~nm}$ wavelengths. Hence, $222 \mathrm{~nm}$ wavelength was selected for DPT and IS determination, respectively.

System suitability tests are used to verify that reproducibility of the chromatographic system which is adequate for the analysis to be done. Some of the tests were carried out on freshly prepared standard solutions. The retention times of DPT and IS were 5.25 and $3.26 \mathrm{~min}$, respectively. Validated analytical parameters were presented in Table 1 for standard solution and urine sample.

The LOD and LOQ were calculated using the standard deviation $(\mathrm{s})$ of response and the slope $(\mathrm{m})$ of the calibration curve as LOD $=3.3 \mathrm{~s} / \mathrm{m} ; \mathrm{LOQ}=10 \mathrm{~s} / \mathrm{m}[16-19]$. The ratio of the peak area of the studied compound to the IS vs. concentration of the compound was used for the quantitation. The low values of DPT of intercept, slope and $r>0.999$ in mobile phase were established the precision of the proposed method. Typical chromatograms of standart solution and urine samples are shown in Figs. 2 and 3, respectively.

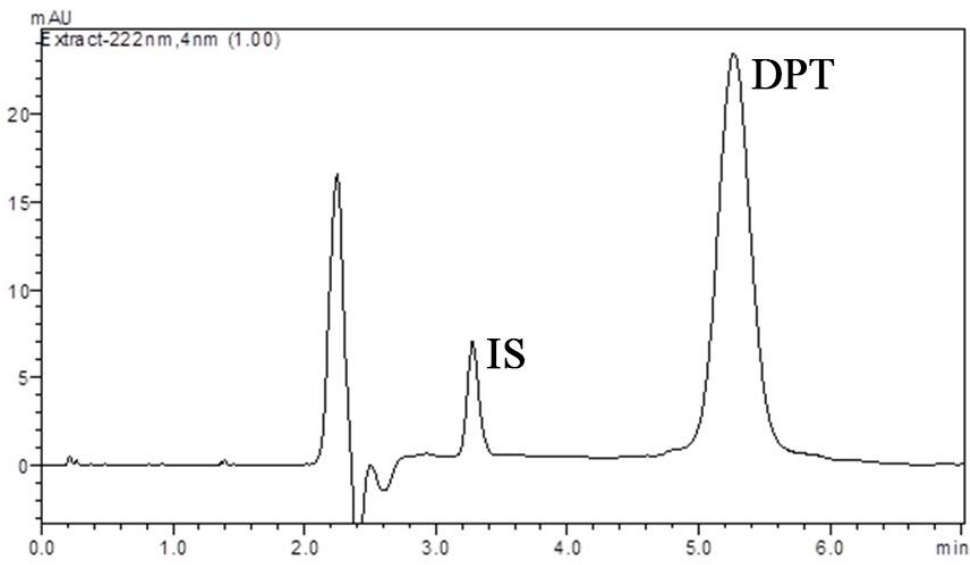

Figure 2. Chromatogram of a standard mixture: DPT $\left(8 \mu \mathrm{g} \mathrm{mL}^{-1}\right)$, IS $\left(2 \mu \mathrm{g} \mathrm{mL}^{-1}\right)$ The monitoring wavelength $222 \mathrm{~nm}$ for IS and DPT. 

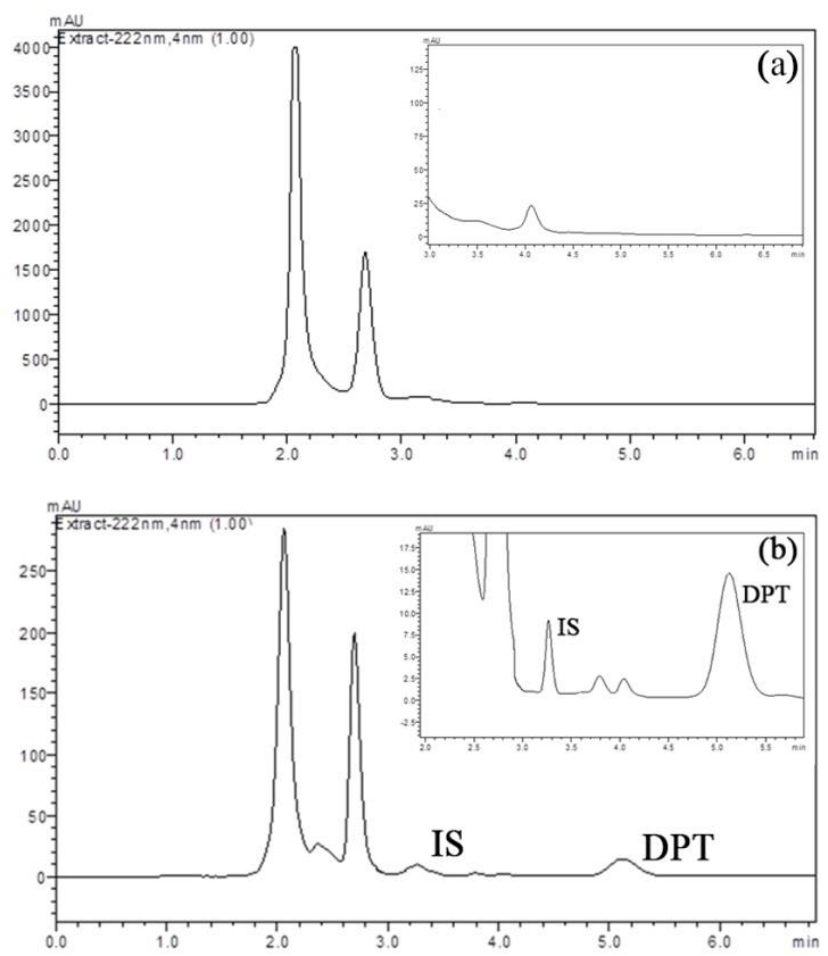

Figure 3. (a): Urine blank (b):Spiked urine sample: DPT $(8 \mu \mathrm{g} \mathrm{mL}-1)$, IS $\left(2 \mu \mathrm{g} \mathrm{mL}^{-1}\right)$ The monitoring wavelength $222 \mathrm{~nm}$ for IS and DPT

Table 1. Regression data of the calibration lines for quantitative determination of DPT in standard solution and in human urine samples by RP-LC method.

\begin{tabular}{lcc}
\hline & Standard Solution & Human Urine \\
\hline Linearity range $\left(\mu \mathrm{g} \mathrm{mL}^{-1}\right)$ & $0.5-12$ & $0.5-12$ \\
Slope & 0.3719 & 0.2343 \\
Intercept & 0.1392 & 0.2005 \\
Correlation coefficient & 0.9996 & 0.9995 \\
S.E. of Slope & 0.0053 & 0.0027 \\
S.E. of intercept & 0.0328 & 0.0164 \\
S.E. of correlation coefficient & 0.0539 & 0.0270 \\
LOD $(\mu \mathrm{g} \mathrm{mL}-1)$ & 0.1176 & 0.1412 \\
LOQ $\left(\mu \mathrm{g} \mathrm{mL}^{-1}\right)$ & 0.3563 & 0.4277 \\
\hline
\end{tabular}

In calibration study, same linear range solutions of DPT were perapred in both standard and application solutions. Repatability and reproducibility pramaters checked with within-day and between day measurements. To show precision of these studies, RSD and Bias \% were eveluated. Within-day variations (RSD and Bias\%) were obtained as 1.96 and 0.75, respectively for standard solution. For urine within-day variations, 1.22 and 0.46 values were calculated for RSD and Bias\%. Between-day variations for DPT in standard solution, RSD and Bias\% were found 2.24 and 1.19, respectively. Between-day variations for DPT in urine solution, RSD and Bias\% were found 2.07 and 1.44, respectively. Hence we can say taht, our proposed method may be used for analysis DPT in standard solutions and application medium (urine). The developed 
method showed that routine quality control and assays of pharmaceutics can be performed. Recovery results also presented us precise method was developed for DPT analysis.

Table 2. Within-day and between-day precision.

\begin{tabular}{|c|c|c|c|c|c|}
\hline & \multirow[b]{2}{*}{$\begin{array}{l}\text { Concentration } \\
\qquad\left(\mu \mathrm{g} \mathrm{mL}^{-1}\right)\end{array}$} & \multicolumn{2}{|c|}{ Within-day } & \multicolumn{2}{|c|}{ Between-day } \\
\hline \multirow{3}{*}{ Standart solution } & & $\begin{array}{c}\text { Mean recovery }{ }^{a}, \\
\% \pm \mathrm{RSD}\end{array}$ & Bias \% & $\begin{array}{c}\text { Mean recovery }^{a}, \\
\% \pm \mathrm{RSD}\end{array}$ & Bias \% \\
\hline & 1 & $100.75 \pm 1.96$ & 0.75 & $101.19 \pm 2.24$ & 1.19 \\
\hline & 8 & $100.35 \pm 0.33$ & 0.35 & $100.29 \pm 0.39$ & 0.29 \\
\hline \multirow[t]{2}{*}{ In urine } & 1 & $100.46 \pm 1.22$ & 0.46 & $101.44 \pm 2.07$ & 1.44 \\
\hline & 8 & $100.12 \pm 0.46$ & 0.12 & $100.38 \pm 0.41$ & 0.38 \\
\hline
\end{tabular}

aEach value is the mean the three experiments.

\section{DISCUSSION}

With the condition which was described above, RP-HPLC methods were used to analyze for DPT which were respectively subjected to hydrolysis (acidic or alkaline), oxidation, photolysis or thermal stress conditions. The results suggested the degradation behavior as follow. Alkali degradation of DPT is about double relatively acid. DPT was completely degraded under peroxide. Degradation studies showed that DPT is more stable than the other stress conditions when exposed to UV light ( 6 and $24 \mathrm{~h})$ and heated (100 oC for 6 and $24 \mathrm{~h}$ ). Table 3 shows the results of the forced degradation studies using the developed method, indicating degradation percentage and purity of drug peak in the chromatograms (Fig. 4).

Table 3. The RP-LC results of hydrolytic, oxidizing, thermal and photolytic stress conditions of drug.

\begin{tabular}{lc}
\hline Stress conditions & Degradation of DPT \% \\
\hline $\mathrm{HCl}(1.0 \mathrm{M})$ & 35.30 \\
$\mathrm{NaOH}(1.0 \mathrm{M})$ & 61.77 \\
$\mathrm{H}_{2} \mathrm{O}_{2}(3 \%)$ & 100 \\
$\mathrm{UV}(6 \mathrm{~h})$ & 0.53 \\
$\mathrm{UV}(24 \mathrm{~h})$ & 1.35 \\
$\mathrm{Heating}(100 \circ \mathrm{C} 6 \mathrm{~h})$ & 2.39 \\
\hline Heating $(100 \circ \mathrm{C} 24 \mathrm{~h})$ & 10.13 \\
\hline
\end{tabular}



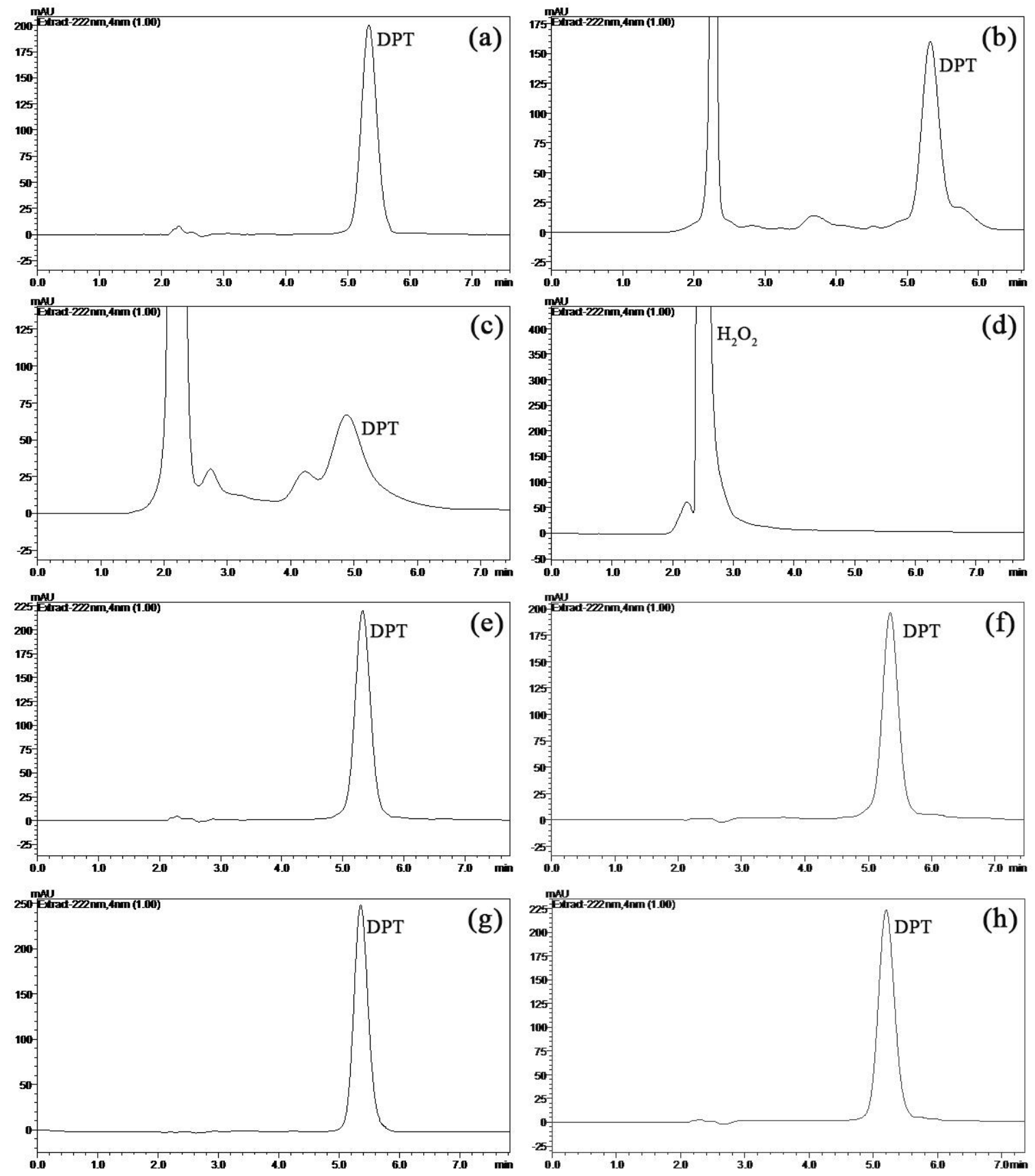

Figure 4. Typical LC chromatograms of drugs under drastic stressed conditions: (a) $100 \mu \mathrm{g} \mathrm{mL}^{-1} \mathrm{DPT}$, (b) 1.0 $\mathrm{M} \mathrm{HCl}$ at $75{ }^{\circ} \mathrm{C}$ after $30 \mathrm{~min}$, (c) $1.0 \mathrm{M} \mathrm{NaOH}$ at $75{ }^{\circ} \mathrm{C}$ after $30 \mathrm{~min}$, (d) $\mathrm{H}_{2} \mathrm{O}_{2} 3 \%$ at $75{ }^{\circ} \mathrm{C}$ after $30 \mathrm{~min}$, (e) in UV light (360 nm) after $6 \mathrm{~h}$, (f) in UV light (360 nm) after $24 \mathrm{~h},(\mathrm{~g})$ at $100{ }^{\circ} \mathrm{C}$ after $6 \mathrm{~h}$ and (h) at $100{ }^{\circ} \mathrm{C}$ after $24 \mathrm{~h}$.

\section{CONCLUSION}

A fast, sensitive, precise RP-LC method was developed for DPT in standard solution and human urine sample. DPT response could be obtained in short time such as $<6 \mathrm{~min}$ by X-Terra column. Any antibacterial drug or finished product may be quantified with developed method because of validation parameters. When compared with previous reported methods, this proposed method has the advantages of recovery, reproducibility, sensitivity and requires less expensive reagents. The results of stress testing undertaken according to the International Conference on Harmonization (ICH) guidelines reveal that this method is 
selective and stability. The proposed method has the ability to separate these drugs from their degradation products and related substances. This method can be used for routine analysis in pharmaceutical industry.

\section{MATERIALS AND METHODS}

All reagents and solvents were analytical grade and used with no further purification. DPT was purchased from Deva ${ }^{\circledR}$ (Istanbul, Turkey) and Tinidazole (IS) was obtained Pfizer ${ }^{\circledR}$ (Istanbul, Turkey). HPLC grade acetonitrile (ACN) was purchased from Merck (Darmstadt, Germany). Orthophosphoric acid (85\%, d:1.71 $\mathrm{g} \mathrm{mL}^{-1}$ ) was obtained from Merck (Darmstadt, Germany). Sodium hydroxide, hydrochloric acid (37\%, d:1.19 $\mathrm{g} \mathrm{mL}^{-1}$ ) and hydrogen peroxide (35\%, d: $1.13 \mathrm{~g} \mathrm{~mL}^{-1}$ ) were supplied from Riedel-de Haen (Seelze, Germany). Ultra-pure water was produced in the laboratory with conductivity $18.21 \mathrm{~S} \mathrm{~cm}^{-1}$ was obtained using a Zeneer Power I water system (Human Corp. Korea) and pure water was used to preparation of all aqueous solutions.

The liquid chromatography (LC) analysis was performed on a Shimadzu HPLC system with a pump (LC-20 AD), a DAD detector system (SPD-M 20A) and column oven (CTO $20 \mathrm{AC}$ ). This equipment has a degasser system (DGU $20 \mathrm{~A}$ ). The system operates at $222 \mathrm{~nm}$ for DPT and $319 \mathrm{~nm}$ for tinidazole (IS). An XTerra RP-18 $(250 \times 4.60 \mathrm{~mm}$ ID $\times 5 \mu)$ column was used as stationary phase at $25^{\circ} \mathrm{C}$. To arrange $\mathrm{pH}$ value of solutions, Mettler Toledo MA $235 \mathrm{pH} /$ ion analyzer with Hanna HI $1332 \mathrm{Ag} / \mathrm{AgCl}$ combined glass electrode was used.

$45: 50 \%(\mathrm{v} / \mathrm{v}$ ) acetonitrile-water mixture containing $20 \mathrm{mM}$ o-phosphoric acid was used as the mobile phase during this study. The mobile phase was adjusted to $\mathrm{pH} 3.0$ with $1 \mathrm{M} \mathrm{NaOH}$. The column was preconditioned during at least $1 \mathrm{~h}$ at low flow rate $\left(0.5 \mathrm{~mL} \mathrm{~min}^{-1}\right)$. The flow rate was maintained at $1.5 \mathrm{~mL} \mathrm{~min}^{-1}$ and the injected volume was $20 \mu \mathrm{L}$. Stock solutions of $100 \mu \mathrm{g} \mathrm{mL}^{-1} \mathrm{DPT}$ and $100 \mu \mathrm{g} \mathrm{mL}^{-1}$ IS were prepared in deionized water by using volumetric flasks and stored at $+4{ }^{\circ} \mathrm{C}$.

DPT was prepared by dissolving in mobile phase at concentration range of $0.5-12 \mu \mathrm{g} \mathrm{mL}^{-1}$ for drawing the calibration line. The linear range of DPT was varied in the range of $0.5-12 \mu \mathrm{g} \mathrm{mL}^{-1}$ for urine analysis. The calibration curves for RP-LC analysis were performed by plotting the ratio of the peak area of DPT to that of IS against the DPT concentration. $2 \mu \mathrm{g} \mathrm{mL}^{-1}$ was used as fixed concentration value for IS in each solution for calibration study.

Degradation studies were attempted to stress condition of acid, base, oxidation, heat in oven $\left(a t 100^{\circ} \mathrm{C}\right)$ and UV light, to evaluate the ability of the proposed method to detect DPT from its degradation product [15]. For hydrolytic and oxidative degradation, solutions were prepared by dissolving drug in deionized water and then diluted with hydrochloric acid, sodium hydroxide or hydrogen peroxide solution, to achieve a concentration of $100 \mu \mathrm{g} \mathrm{mL}^{-1}$ of DPT for each solution. Acid and alkaline hydrolysis of drug substance in solution state was conducted with $1.0 \mathrm{M} \mathrm{HCl}$ and $1.0 \mathrm{M} \mathrm{NaOH}$ at $75{ }^{\circ} \mathrm{C}$ during $30 \mathrm{~min}$. Sample solutions of drug substance and drug product were kept in $3 \%$ hydrogen peroxide at $75{ }^{\circ} \mathrm{C}$ during $30 \mathrm{~min}$. for oxidative stress. Thermal and photo-degradation of drug substance was carried out in solid state. After the degradation, stock solutions were prepared by dissolving in deionized water to achieve a concentration of $100 \mu \mathrm{g} \mathrm{mL}^{-1}$. For thermal stress, DPT was placed in a controlled-temperature oven at $100{ }^{\circ} \mathrm{C}$ for 6 and $24 \mathrm{~h}$. For photolytic stress, drug sample, in solid state, was irradiated with UV radiation having peak intensities at $360 \mathrm{~nm}$ for 6 and $24 \mathrm{~h}$.

Application study was performed with human urine samples that was taken from a healthy volunteer. An aliquot volume of urine sample was fortified with drug dissolved in $\mathrm{ACN}$ to achieve a final concentration of $100 \mu \mathrm{g} \mathrm{mL}^{-1}$. The fixed amount of IS added also these measurement solutions with urine samples. The calibration study with presence of urine was performed between 0.5 and $12 \mu \mathrm{g} \mathrm{mL}^{-1}$. In the next step, solutions were filtered and analyzed by RP-LC.

Author contributions: Concept-N.K.B., B.A.; Design-B.A.; Supervision-S.A.O., N.K.B.; Resources-T.G.; Materials-B.A, T.G.; Data Collection-B.A.; Literature Search-T.G; Writing-N.K.B.; S.A.O; Critical Review- B.A., T.G., S.A.O., N.K.B

Conflict of interest statement: The authors declared no conflict of interest.

\section{REFERENCES}

[1] Taylor SD, Palmer M. The action mechanism of daptomycin. Bioorg Med Chem. 2016; 24: 6253-6268. [CrossRef]

[2] Johnson A. Daptomycin in the treatment of skin, soft-tissue and invasive infections due to Gram-positive bacteria. Future Microbiol. 2006; 1: 255-265. [CrossRef] 
[3] Ogami C, Tsuji Y, Kasai H, Hiraki Y, Yamamoto Y, Matsunaga K, Karube Y, To H. Evaluation of pharmacokinetics and the stability of daptomycin in serum at various temperatures. Int J Infect Dis. 2017; 57: 38-43 [CrossRef]

[4] Wu G, Abraham T, Rapp J, Vastey F, Saad N, Balmir E. Daptomycin evaluation of a high-dose treatment strategy. Int J Antimicrob Agents. 2011; 38: 192-196. [CrossRef]

[5] Seaton RA, Menichetti F, Dalekos G, Beiras-Fernandez A, Nacinovich F, Pathan R, Hamed K. Evaluation of effectiveness and safety of high-dose daptomycin: results from patients included in the European Cubicin1 Outcomes Registry and Experience. Adv Ther. 2015; 32(12): 1192-1205. [CrossRef]

[6] Deryke CA, Sutherland C, Zhang B, Nicolau DP, Kuti JL. Serum bactericidal activities of high-dose daptomycin with and without co administration of gentamycin against isolates of Staphylococcus aureus and Enterococcus species. Antimicrob Agents Chemother. 2006; 50 (11): 3529-3534.

[7] Gikas E, Bazoti FN, Fanourgiakis P, Perivolioti E, Roussidis A, Skoutelis A, Tsarbopoulos A. Development and validation of a UPLC-UV method for the determination of daptomycin in rabbit plasma. Biomed Chromatogr. 2009; 24(5): 522-527. [CrossRef]

[8] Baietto L, D’Avolio A, Rosa FG, Garazzino S, Michelazzo M, Ventimiglia G, Siccardi M, Simiele M, Sciandra M, Di Perri, G. Development and validation of a simultaneous extraction procedure for HPLC-MS quantification of daptomycin, amikacin, gentamicin, and rifampicin in human plasma. Anal Bioanal Chem. 2010; 396(2): 791-798.

[9] Christ AP, Machado MS, Rosa P, Codevilla CF, Rolim CMB, Adams AIH. Development and validation of a stabilityindication LC-UV method for determination of daptomycin injectable form and kinetic study in alkaline medium. Anal Methods. 2014; 6(4): 1242- 1247.

[10] Christ AP, Machado MS, Ribas KG, Schwarzbold AV, Silva CB, Adams AIH. A fully validated microbiological assay for daptomycin injection and comparison to HPLC method. Braz J Pharm Sci. 2015; 51-55.

[11] ICH guidelines, Q1A(R2): Stability Testing of New Drug Substances and Products (revision 2), International Conference on Harmonization., 2003.

[12] Reynolds DW, Facchine KL, Mullaney JF. Available guidance and best practices for conducting forced degradation studies. Pharm Technol. 2002; 26(2): 48-56.

[13] Brummer H. How to approach a forced degradation study. Life Sci Technol Bull. 2011; 31: 1-4.

[14] Blessy M, Ruchi DP, Prajesh N, Prajapati YK. Agrawal. Development of forced degradation and stability indicating studies of drugs - A review. J Pharm Anal. 2014; 4(3): 159-165. [CrossRef]

[15] ICH, Stability Testing of New Drug Substances and Products (Q1AR): International Conference on Harmonization, IFPMA, Geneva, 2000

[16] Tambe SR, Shinde RH, Gupta LR, Pareek V, Bhalerao SB. Thin layer chromatography in drug analysis. J Liq Chrom Rel Tech. 2010; 33(4): 423.

[17] Ermer J, Miller JH. Method validation in pharmaceutical analysis, 1st Edn. Wiley_VCH Pub, Germany, 2005.

[18] Topic Q2A, Validation of Analytical Procedures, Methodology, International Conference on Harmonization, Brussels, Belgium, 1995.

[19] Riley CM, Rosanske TW. Development and Validation of Analytical Methods. Amsterdam: Elsevier, 1996. 